\title{
Serum Cholesterol Levels in Neutropenic Patients with Fever
}

Peter Fraunberger ${ }^{*}$, Joachim Hahn², Ernst Holler², Autar K. Walli ${ }^{1}$ and Dietrich Seidel ${ }^{1}$

1 Department of Clinical Chemistry, University Hospital Großhadern, Munich, Germany

2 Department of Hematology and Oncology, University of Regensburg, Germany

Hypocholesterolemia, which often accompanies infectious diseases has been suggested to serve as a prognostic marker in hospitalized patients. Even though patients with chemotherapy-induced leukopenia are at high risk of infection and mortality, only limited information is available on serum cholesterol levels in these patients. We therefore measured serum cholesterol levels in 17 patients with hematological malignancies during chemotherapy-induced neutropenia and correlated it with clinical outcome. Patients with fever $\left(>38.5{ }^{\circ} \mathrm{C}\right)$ showed a significant decrease in serum cholesterol levels within 24 hours. Eight days after onset of the fever non-survivors had significantly lower serum cholesterol levels (median $2.09 \mathrm{mmol} / \mathrm{l}$, range $0.49-2.79, \mathrm{n}=6$ ) compared to survivors (median $3.23 \mathrm{mmol} / \mathrm{l}$, range $1.68-4.86, \mathrm{n}=11$ ). Cholesterol levels in survivors returned to baseline levels at the time of discharge from the hospital. At the onset of fever, serum levels of inflammatory cytokines interleukin-6, tumor necrosis factor (TNF) and soluble TNF receptors p55 and p75 were elevated in all patients, but only TNF and TNF receptor p75 levels were significantly different in survivors and non-survivors.

Our data suggest that a decrease in serum cholesterol levels is a prognostic marker in neutropenic patients with fever. Release of inflammatory cytokines may in part be responsible for hypocholesterolemia in these patients. Clin Chem Lab Med 2002; 40(3):304-307

Key words: Cholesterol; Neutropenic; Fever; Sepsis; Interleukin-6 (IL-6); Tumor necrosis factor (TNF).

Abbreviations: CRP, C-reactive protein; FUO, fever of unknown origin; IL, interleukin; NHL, non-Hodgkin lymphoma; sTNF-R, soluble TNF receptor; TNF, tumor necrosis factor; WBC, white blood count.

\section{Introduction}

A reduction in serum cholesterol levels during the acute phase response to various conditions such as in-

*E-mail of the corresponding author:

peter.fraunberger@klch.med.uni-muenchen.de fection (1-3), surgery (4), burn injury (5), sepsis and multiorgan failure (6) has been described in humans. The degree of hypocholesterolemia under these conditions may reflect the severity of disease. In addition, numerous recent studies indicate that low cholesterol levels are associated with increased mortality (6-8). In a large population of hospitalized patients prognostic value of serum cholesterol has been reported irrespective of the underlying disease (9).

Patients with chemotherapy-induced neutropenia are at high risk of bacterial infectious disease and frequently develop fever which may lead to mortality (10). Even though cytokine levels were elevated in these patients and increased interleukin-6 (IL-6) levels determined the mortality (11), no data on serum cholesterol levels are available. In order to examine the prognostic value of cholesterol concentration, we measured its serum levels in neutropenic patients at the time of onset of fever in response to infection and correlated these levels with clinical outcome. Although the underlying mechanism for low serum cholesterol levels in inflammatory conditions is still unclear, studies in experimental animals suggest that cytokines which are released during inflammation modulate lipoprotein metabolism. It has also been reported that infusion of IL-1 and tumor necrosis factor (TNF) (12-14) in experimental animals, as well as TNF (15), IL-2 (16), IL-6 (17) in cancer patients, diminishes plasma cholesterol levels. This suggests that cytokines may in part be responsible for the hypocholesterolemia. We therefore measured serum levels of IL-6, TNF and soluble TNF receptors (sTNF-R) in order to establish whether circulating levels of these proinflammatory cytokines correlate with serum cholesterol levels.

\section{Patients, Materials and Methods}

\section{Patients and blood sampling}

Patients with the following oncological diagnoses were included in the study: 11 with acute myeloid leukemia, 2 with acute lymphocytic leukemia, 2 with chronic myeloid leukemia, 1 with non-Hodgkin lymphoma (NHL) and 1 with testicular cancer. All patients undergoing intensive chemotherapy developed severe leukopenia (white blood count (WBC) $<1 \times 10^{9} /$ l). Clinical course was followed by daily monitoring of fever, the signs of infection (e.g. blood cultures), medication (antibiotics, transfusion) and clinical chemistry parameters (WBC, hemoglobin and C-reactive protein (CRP)). Patients were included in the study at the onset of fever $>38.5^{\circ} \mathrm{C}$ which was unrelated to changes in transfusion or drug therapy and were followed for 1 week. Cholesterol was measured at the onset of fever and subsequently on day 2, 4, 8 and at discharge. Cholesterol values prior to chemotherapy were obtained from hospital charts. Aliquots of serum obtained at the 
onset of fever were stored at $-70^{\circ} \mathrm{C}$ for the measurement of cytokines. In addition, blood samples were collected from six healthy volunteers who showed no signs of fever or infection and had normal WBC.

\section{Analytical techniques}

Serum levels of cholesterol and triglycerides were measured with Hitachi automated system (Boehringer Mannheim, Mannheim, Germany). Serum TNF and IL-6 levels were measured with a commercial enzyme-linked immunosorbent assay (Biosource Europe, Nivelles, Belgium). Both assays have a detection limit of $<3 \mathrm{pg} / \mathrm{ml}$. sTNF-R p55 and p75 were measured automatically on CobasCore with enzyme-linked immunobinding assays (Hoffmann La Roche Ltd., Basel Switzerland). The receptor assay has a detection limit of 100 $\mathrm{pg} / \mathrm{ml}$ and is not affected by the presence of free or unbound TNF at a concentration below $10 \mathrm{ng} / \mathrm{ml}$ (18).

\section{Statistics}

Values for lipid and cytokine measurements are given as median and range. Statistical significance was calculated using Mann-Whitney-Wilcoxon-test test and a p-value $<0.05$ was considered significant.

\section{Results}

Eleven out of 17 patients included in this study showed positive blood cultures. Pathogens included Staphylococcus aureus $(n=3)$, Streptococcus spp $(n=4)$, Enterococcus faecalis $(n=1)$, Pseudomonas aeruginosa $(n=1)$ and Candida albicans $(\mathrm{n}=2)$. In the remaining six patients blood cultures were negative. Three of these patients developed clinical and radiological signs of bilateral pneumonia without the presence of bacterial or fungal pathogens either at the time of first symptoms or during ventilation. In the remaining three patients fever was classified as fever of unknown origin (FUO) (Table 1).

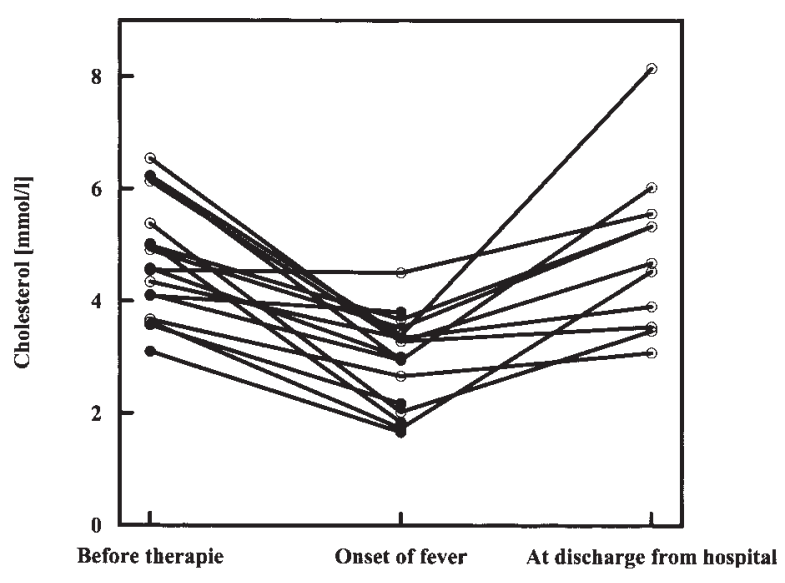

Figure 1 Serum cholesterol levels in all patients before therapy, at the onset of fever and at discharge from hospital (survivors only). $\bigcirc$ survivors, $\bullet$ non-survivors.

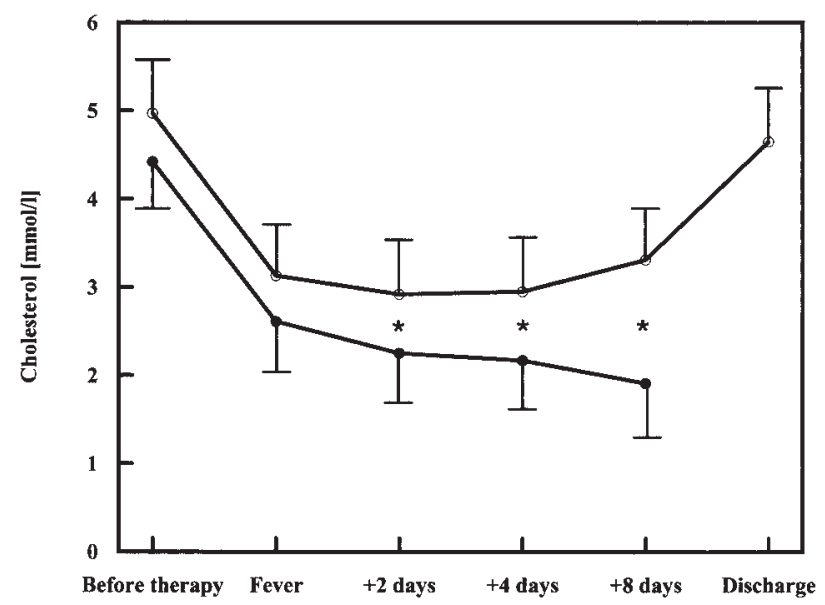

Figure 2 Mean serum cholesterol levels of survivors $(O)$ and non-survivors (0) during the observation period. On day 8 after the onset of fever, cholesterol levels were available from only 16 patients because one patient died between day 4 and 8. * ${ }^{*}$ statistically different from non-survivors, $p<0.05$.

Table 1 Characteristics of patients enrolled in the study.

\begin{tabular}{rllll}
\hline No & Underlying disease & Underlying cause of fever & Pathogen & Outcome \\
\hline 1 & AML & FUO & - & Survived \\
2 & AML & Septicopyaemia & Candida albicans & Died \\
3 & NHL & Sepsis & Streptococcus mitis & Died \\
4 & AML & Pneumonia & - & Died \\
5 & Testicular cancer & Bacteremia & Enterococcus faecalis & Survived \\
6 & AML & Bacteremia & Streptococcus mitis & Survived \\
7 & AML & Bacteremia & Streptococcus mitis & Survived \\
8 & ALL & Pneumonia & Staphylococcus aureus & Died \\
9 & AML & Sepsis & Pseudomonas aerug. & Survived \\
10 & AML & Sepsis & Streptococcus pyogenes & Died \\
11 & ALL & FUO & - & Survived \\
12 & AML & Bacteremia & Staphylococcus aureus & Survived \\
13 & AML & Pneumonia & - & Died \\
14 & CML & Septicopyaemia & Candida albicans & Survived \\
15 & AML & Bacteremia & Staphylococcus aureus & Survived \\
16 & CML & Pneumonia & - & Survived \\
17 & AML & FUO & - & Survived \\
\hline
\end{tabular}

$A M L$, acute myeloid leukemia; $N H L$, non-Hodgkin lymphoma; $A L L$, acute lymphocytic leukemia;

$\mathrm{CML}$, chronic myeloid leukemia; FUO, fever of unknown origin 
Table 2 Serum cytokine and CRP levels in survivors and non-survivors at the onset of fever.

\begin{tabular}{llllll}
\hline Outcome & $\begin{array}{l}\text { IL-6 } \\
(\mathrm{pg} / \mathrm{ml})\end{array}$ & $\begin{array}{l}\text { TNF } \\
(\mathrm{pg} / \mathrm{ml})\end{array}$ & $\begin{array}{l}\text { sTNF-R p55 } \\
(\mathrm{ng} / \mathrm{ml})\end{array}$ & $\begin{array}{l}\text { sTNF-R p75 } \\
(\mathrm{ng} / \mathrm{ml})\end{array}$ & $\begin{array}{l}\text { CRP } \\
(\mathrm{mg} / \mathrm{dl})\end{array}$ \\
\hline $\begin{array}{l}\text { Survivors } \\
(\mathrm{n}=11)\end{array}$ & 230 & 18 & 2.6 & 5.0 & 8.0 \\
$\begin{array}{l}\text { Non-survivors } \\
(\mathrm{n}=6)\end{array}$ & $(8-603)$ & $(3-36)$ & $(1.4-3.7)$ & $(2.4-8.8)$ & $(2.0-21.0)$ \\
$\mathrm{p}$ & $(122-1000)$ & $(18-84)$ & $(1.8-13.4)$ & $(4.4-21.0)$ & $(1.3-23.4)$ \\
\hline
\end{tabular}

Values are given as median (range), ns=not significant

Onset of fever during chemotherapy-induced neutropenia significantly decreased median serum cholesterol levels from $4.58 \mathrm{mmol} / \mathrm{l}$ (range 3.10-6.54) to 3.00 $\mathrm{mmol} / \mathrm{l}$ (range 1.73-4.50) (Figure 1). Cholesterol levels in all patients showed a tendency to decrease further on the second (median $2.64 \mathrm{mmol} / \mathrm{l}$, range 1.66-3.49) and fourth day (median $2.59 \mathrm{mmol} / \mathrm{l}$, range $0.49-2.79$ ). However, these changes were statistically not significant. Cholesterol levels in non-survivors $(n=6)$ on day 2,4 , and 8 were $2.20 \mathrm{mmol} / \mathrm{l}$ (range 1.66-3.18), $2.02 \mathrm{mmol} / \mathrm{l}$ (range 1.66-3.16) and $2.10 \mathrm{mmol} / \mathrm{l}$ (range $0.49-2.79$ ), respectively. In eleven survivors cholesterol levels were significantly higher $(p<0.05)$ on day 2,4 and 8 (3.13 $\mathrm{mmol} / \mathrm{l}$, range $1.76-3.49,2.79 \mathrm{mmol} / \mathrm{l}$, range $1.68-3.91$ and $3.23 \mathrm{mmol} / \mathrm{l}$, range $1.68-4.86$; respectively) and returned to nearly baseline values of $4.68 \mathrm{mmol} / \mathrm{l}$ (range 3.08-8.15) at the time of discharge (Figure 2).

At the onset of fever, median serum levels of IL-6, TNF and sTNF-R were significantly higher in the patients compared to healthy controls (IL-6: $230 \mathrm{pg} / \mathrm{ml}$ (range 8-1000) vs. $3 \mathrm{pg} / \mathrm{ml}$ (range 3-11); TNF: $19 \mathrm{pg} / \mathrm{ml}$ (range 3-84) vs. $12 \mathrm{pg} / \mathrm{ml}$ (range 8-26); sTNF-R p55: 2.6 $\mathrm{ng} / \mathrm{ml}$ (range 1.4-13.4) vs. $1.8 \mathrm{ng} / \mathrm{ml}$ (range 0.8-2.4); sTNF-R p75: $7.0 \mathrm{ng} / \mathrm{ml}$ (range 2.4-21.0) vs. $2.5 \mathrm{ng} / \mathrm{ml}$ (range 0.9-3.4), respectively). Serum levels of cytokines and CRP of survivors and non-survivors are summarized in Table 2. Serum levels of IL-6, TNF and sTNF-R p55 and p75 were higher in non-survivors compared to survivors. However, only values for TNF and sTNF-R p75 were statistically significant $(p<0.05)$. There was no significant difference in IL-6 levels between survivors and non-survivors (median $230 \mathrm{pg} / \mathrm{ml}$ (range 8-603) and $601 \mathrm{pg} / \mathrm{ml}$ (range 122-1000), respectively), even though the highest IL-6 levels ( $>1000$ $\mathrm{pg} / \mathrm{ml}$ ) were observed in three out of six non-survivors.

\section{Discussion}

Neutropenic patients with fever are at high risk of mortality due to infectious diseases (19). However, in many febrile episodes no causative organism is found and fever is classified as FUO. It is therefore necessary to identify some additional laboratory parameters other than CRP and cytokines which could identify those patients who are at high risk of mortality. There are only a few studies which report that development of sudden hypocholesterolemia in critically ill patients is associated with mortality (20). We therefore followed the serum cholesterol and cytokine levels in neutropenic patients. In the present study a drastic reduction in serum cholesterol was observed in neutropenic patients with fever. In all six patients who did not survive, a reduction in serum cholesterol persisted during their stay in hospital. In contrast, serum cholesterol levels were higher in survivors and returned to values similar to those prior to the onset of fever at the time of discharge from hospital.

Previous studies have shown that not only bacterial and viral infections $(3,21,22)$ but also inflammatory processes such as trauma (4) or autoimmune diseases (23) are associated with low cholesterol levels. Since all the patients in our study developed hypocholesterolemia, it suggests a possible common mechanism for hypocholesterolemia in inflammatory processes. In accordance with previous studies, we found increased cytokine levels at the onset of fever during neutropenia $(11,24,25)$. An increase in serum TNF and its soluble receptors at the onset of fever was accompanied by a reduction of cholesterol, possibly due to increased removal of circulating lipoproteins (18) or diminished synthesis rates (26).

In summary, our data, even though based on a small number of patients, indicate that serum cholesterol is a reliable marker for prognosis and may serve as an additional therapy control in neutropenic patients with fever. However, it needs to be confirmed on a larger cohort. The association of hypocholesterolemia with increased cytokine levels supports the hypothesis that the systemic release of cytokines plays a role in lowering cholesterol during inflammation.

\section{References}

1. Alvarez C, Ramos A. Lipids, lipoproteins, and apoproteins in serum during infection. Clin Chem 1986; 32:142-5.

2. Sammalkorpi K, Valtonen V, Kertulla Y, Nikkilä E, Taskinen M-R. Changes in serum lipoprotein pattern induced by acute infections. Metabolism 1988; 37:859-5.

3. Akerlund B, Carlson LA, Jarstrand C. Dyslipoproteinemia in patients with severe bacterial infections. Scand J Infect Dis 1986; 18:539-5. 
4. Werner M, Cohnen G. Changes in serum proteins in the immediate postoperative period. Clin Sci 1969; 36:173-84.

5. Coombes EJ, Shakespeare PG, Batstone GF. Lipoprotein changes after burn injury in man. J Trauma 1980; 20:971-5.

6. Fraunberger P, Nagel D, Werdan K, Walli AK, Seidel D. Serum cholesterol and mortality in patients with multiple organ failure. Crit Care Med 2000; 28:3574-5.

7. Jacobs D, Blackburn H, Higgins $M$, Reed D, Iso H, McMillan $\mathrm{G}$, et al. Report of the Conference on Low Blood Cholesterol: Mortality Associations. Circulation 1992; 86:1046-60.

8. Pacelli F, Doglietto GB, Alfieri S, Piccioni E, Sgadari A, Gui $D$, Crucitti F. Prognosis in intra-abdominal infections. Multivariate analysis on 604 patients. Arch Surg 1996; 131: 641-5.

9. Windler E, Ewers-Grabow U, Thiery J, Walli A, Seidel D, Greten $\mathrm{H}$. The prognostic value of hypocholesterolemia in hospitalized patients. Clin Invest 1994; 72:939-43.

10. Pizzo PA. Management of fever in patients with cancer and treatment-induced neutropenia. N Engl J Med 1993; 328: 1323-32.

11. Herrmann JL, Blanchard $\mathrm{H}$, Brunengo $\mathrm{P}$, Lagrange $\mathrm{PH}$. TNF alpha, IL-1 beta and IL-6 plasma levels in neutropenic patients after onset of fever and correlation with the C-reactive protein (CRP) kinetic values. Infection 1994; 22:309-15.

12. Ettinger WH, Miller LA, Smith TK, Parks JS. Effect of interleukin-1 alpha on lipoprotein lipids in cynomolgus monkeys: comparison to tumor necrosis factors. Biochim Biophys Acta 1992; 1128:186-92.

13. Ettinger WH, Miller LD, Albers JJ, Smith TK, Parks JS. Lipopolysaccharide and tumor necrosis factor cause a fall in plasma concentration of lecithin: cholesterol acyltransferase in cynomolgus monkeys. J Lipid Res 1990; 31:1099107.

14. Hermus R, Sweep C, Demacker P, van der Meer M, Kloppenborg $P$, ven der Meer J. Continous infusion of interleukin-1 $\beta$ in rats induces a profound fall in plasma levels of cholesterol and triglycerides. Aterioscler Throm 1992; 12:1036-43.

15. Spriggs DR, Sherman ML, Michie H, Arthur KA, Imamura $\mathrm{K}$, Wilmore $\mathrm{D}$, et al. Recombinant human tumor necrosis factor administered as a 24-hour intravenous infusion. A phase I and pharmacologic study. J Natl Cancer Inst 1988; 80:1039-44.

16. Rosenzweig IB, Wiebe DA, Hank JA, Albers JJ, Adolphson $\mathrm{JL}$, Borden $\mathrm{E}$, et al. Effects of interleukin-2 (IL-2) on human plasma lipid, lipoprotein, and C-reactive protein. Biotherapy $1990 ; 2: 193-8$.
17. van Gameren MM, Willemse PHB, Mulder NH, Limburg PC, Groen HJM, Vellenga E, et al. Effects of recombinant interleukin-6 in cancer patients: a phase I-II study. Blood 1994; 5:1434-41.

18. Fraunberger P, Pilz G, Cremer P, Werdan K, Walli AK. Association of TNF serum levels with decrease of cholesterol during septic shock. Shock 1998, 10:359-63.

19. Bodey GP, Buckley M, Sathe YS, Freireich EJ. Quantitative relationships between circulating leukocytes and infection in patients with acute leukemia. Ann Intern Med 1966; 64:328-40.

20. Elliot DC, Wiles CE. Low lipid concentrations in critical illness: Hypocholesterolemia among trauma patients [letter]. Crit Care Med 1997; 25:1437-9.

21. Vergani C, Trovato G, Delu A, Pietrogrande M, Dioguardi N. Serum total lipids, lipoprotein cholesterol, and apolipoprotein $A$ in acute viral hepatitis and chronic liver disease. J Clin Pathol 1978; 31:772-8.

22. Lees RS, Fiser RH Jr, Beisel WR, Bartelloni PJ. Effects of an experimental viral infection on plasma lipid and lipoprotein metabolism. Metabolism 1972; 21:825-33.

23. Lazarevic MB, Vitic J, Mladenovic V, Myones BL, Skosey $\mathrm{JL}$, Swedler WI. Dyslipoproteinemia in the course of active rheumatoid arthritis. Semin Arthritis Rheum 1992; 22:172-8.

24. Steinmetz HT, Herbertz A, Bertram M, Diehl V. Increase in interleukin-6 serum level preceding fever in granulocytopenia and correlation with death from sepsis. J Infect Dis 1995; 171:225-8.

25. Engel A, Kern WV, Murdter G, Kern P. Kinetics and correlation with body temperature of circulating interleukin-6, interleukin-8, tumor necrosis factor alpha and interleukin-1 beta in patients with fever and neutropenia. Infection 1994; 22:160-4.

26. Ettinger WH, Varma VK, Sorci-Thomas M, Parks JS, Sigmon RC, Smith TK, et al. Cytokines decrease apolipoprotein accumulation in medium from HepG2 cells. Arterioscler Throm 1994; 14:8-13.

Received 19 July 2001, revised 29 January 2002, accepted 31 January 2002

Corresponding author: Dr. med. Peter Fraunberger, Department of Clinical Chemistry, Klinikum Großhadern, University of Munich, Marchioninistr. 15, 81366 Munich, Germany

Phone: +49-89-7095-3234, Fax: +49-89-7095-8888

E-mail: peter.fraunberger@klch.med.uni-muenchen.de 